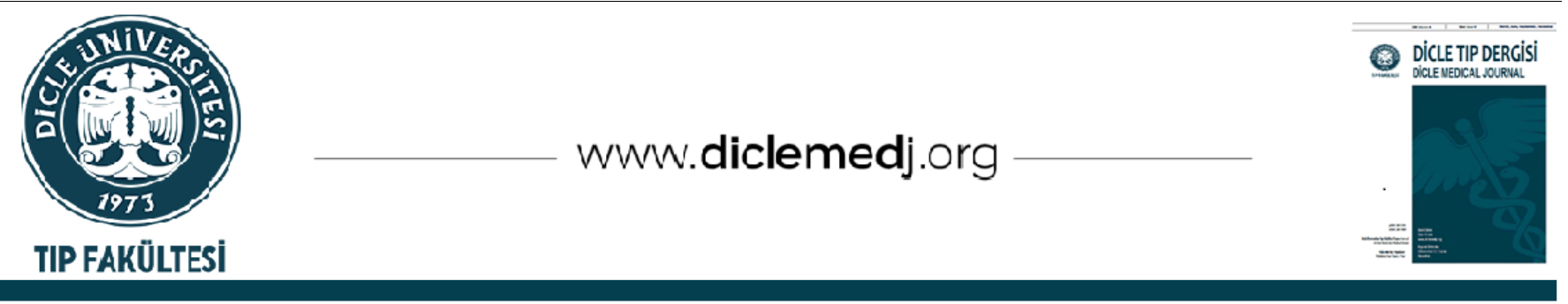

Derleme / Review

\title{
CoviD-19 Kritik Hasta: Analjezi ve Sedasyon
}

\author{
Gönül Ölmez Kavak ${ }^{1}$ \\ 1 Dicle Üniversitesi, Tıp Fakültesi, Anesteziyoloji ve Reanimasyon AD Diyarbakır, Türkiye \\ Geliş: 29.09.2021; Kabul Tarihi: 29.09.2021
}

$\ddot{0} \mathbf{z}$

Yoğun bakım ünitesine kabul edilen kritik covid-19 hastaları sıklıkla analjezi ve sedasyona ihtiyaç duymaktadırlar. Hastalığın kendi fizyopatolojik özelliklerinden ve hastalığın şiddetinden, sağlık hizmeti verenlere bulaşmasına yönelik kaygılardan kaynaklanan artmış sedasyon ve analjezi ihtiyacı vardır. Covid-19 kritik bakım hastalarında sedasyon uygulamasının yönetiminde, bireyselleştirilmiş hasta sedasyon ve analjezi yönetimi, çeşitli ajanların yan etki profilleri, hastaya ait özellikler ve ilaçların ulaşılabilirliği göz önünde bulundurulmalıdır. Hasta güvenliğinin artırılması ve yoğun bakım sonuçlarının iyileştirilmesi temel amaçtır.

Anahtar kelimeler: Covid-19, analjezi, sedasyon, kritik hasta

\section{COVID-19 Critical Patient: Analgesia and Sedation}

\begin{abstract}
Critical covid-19 patients admitted to the intensive care unit often require analgesia and sedation. There is an increased need for sedation and analgesia due to the pathophysiological characteristics of the disease itself, the severity of the disease, and concerns about its transmission to healthcare providers. In the management of sedation in Covid-19 critical care patients, individualized patient sedation and analgesia management, side effect profiles of various agents, patient characteristics, and availability of drugs should be considered. Increasing patient safety and improving intensive care outcomes are the main objectives.
\end{abstract}

Keywords: Covid-19, analgesia, sedation, critically ill patients.

DOI: 10.5798/dicletip.1005435

Yazışma Adresi / Correspondence: Gönül Ölmez Kavak, Dicle Üniversitesi, Tıp Fakültesi, Anesteziyoloji ve Reanimasyon AD Diyarbakır, Türkiye e-mail: golmezkavak@gmail.com 


\section{GíRiş}

Yeni bir koronavirüs türü (SARS-CoV-2 ), dünya çapında pandemiye yol açmıştır.

Yeni tip Coronavirüs Hastalığı (COVID-19), primer olarak solunum yolunu etkisi altına alırken, çoklu organ yetersizliğine yol açabilir ve fatal seyredebilir. Akut solunumsal komplikasyonlar uzun süre yoğun bakım ünitesinde yatışı gerektirebilir ve bu hastalarda mortalite ve morbiditenin majör nedenlerinden birini oluşturur ${ }^{1,2}$.

Şiddetli akut hipoksi gelișen hastalar sıklıkla invaziv mekanik ventilasyona ihtiyaç duyulur. $\mathrm{Bu}$ durum etkili analjezi ve sedayon gerektirmektedir3-6. $\mathrm{Bu}$ hastalarda uygun sedasyon; hasta-ventilatör uyumsuzluğu, kazara ekstübasyonlar, devre bağlantılarının kesilmesi gibi problemleri önlediği gibi, refrakter hipoksik solunum yetmezliği olgularında prone pozisyon ve kas gevşetici uygulamalarını kolaylaştırır. Kapp ve ark.ları ${ }^{7}$ tarafından yapılan bir çalışmada; mekanik ventilasyon gerektiren Covid-19 hastalarında, analjezi ve sedasyon ihtiyacı araştırılmıştır. Araştırıcılar; Covid-19 hastalarında ihtiyaç duyulan sedasyon miktarını, daha önceki bir çalışmada tanımlanan ARDS vakaları ile karşılaştırmışlardır. Çalışma sonucuda, Covid 19 enfeksiyonu sonucu gelişen ARDS vakalarında daha yüksek dozda sedasyon ve analjezi ihtiyacı olduğu, buna bağlı olarkta, şiddetli yan etki gelişme potansiyelinin arttığ sonucuna varmışlardır. Bu durum, optimal sedasyonun sağlanması için Covid-19 hastalı̆̆ının patofizyolojisine bağlı kendine has zorluklara işaret etmektedir. Tüm dünyada, pandemiye bağlı artan kritik hasta sayısı, ve aşırı tüketime bağlı, ilaç temin etmedeki endişeleride beraberinde getirmektedir ${ }^{3,4}$.

Analjezi ve sedasyon yoğun bakım hastalarının bakımının ayrılmaz bir parçasıdır.
$\mathrm{Bu}$ hastalar istirahatte ve standart bakım prosedürleri sırasında orta ila şiddetli ağrı hissederler 8,9 . Ayrıca, yoğun bakımda kalma, hem fizyolojik hem de psikolojik yollardan anksiyeteyi tetikler ve yoğun bakıma kabul edilen hastaların yarısından fazlası yoğun bakımda yaşadıklarını veya entübe olduklarını hatırlamaktadırlar ${ }^{10}$. Bu ağrı ve anksiyete önceden var olan sempatik stres yanıtına katkıda bulunur ve endojen katekolamin aktivitesinde artışa, oksijen tüketiminde artışa, taşikardiye, hiperkoagulasyona, metabolizmada artışa ve immünosupresyona yol açar ${ }^{11}$. Yoğun bakım ortamında dinmeyen ağrı ve anksiyete, ciddi ajitasyona yol açabilmektedir. Bu durum, hayat kurtaran tıbbi cihazların -endotrakeal entübasyon tüpü, intravasküler yollar vsçıkmasına yol açabilmektedir. Bu işlemlerin tekrar yapılması sağlık çalışanlarının tekrar bulaş riskini artırabilmektedir. Bu durum, akut olay sırasında önemli fiziksel ve psikolojik strese katkıda bulunabilir ve post-travmatik stres bozukluğu gibi uzun vadeli sonuçlara yol açabilmektedir.

Yeterli ağrı kontrolü ve sedasyon, peak hava yolu basınçlarındaki artışlar nedeniyle ventilatör kaynaklı akciğer hasarına (VILI) neden olarak hasta sonuçlarını olumsuz yönde etkileyebilen ventilatör uyumsuzluğunun önlenmesinde de önemli bir rol oynar5-7.

COVID-19 hastalarının geniş bir klinik prezantasyonu olmasına karşılık, acil servise hipoksi ile başvuranların, hızla kötüleştiği, ve sonuçta entübasyon, pron pozisyonu ve kas gevşetici uygulamasına ihtiyaç duydukları kaydedilmiştir ${ }^{12}$. Sedasyon, nöromüsküler blokörlerin kullanıma izin vermek, istenmeyen ekstübasyonları önlemek ve ventilatör senkronizasyonunu desteklemek covid-19 hasta popülasyonunda özellikle önemlidir³. 
COVID-19'lu yoğun bakım hastalarının hasta profili- genç ve komorbiditesi olmayan hastalarda bu gruba dahildir-, yoğun inflamatuar yanıtlar oluşturma eğilimindedir ${ }^{13}$. $\mathrm{Bu}$ nedenle, bu hastalar alışılmadık derecede yüksek dozlarda sedatif ilaçlara ve sıklıkla birden fazla ajanın uygulanmasına ihtiyaç duyarlar, bu da potansiyel yan etki risklerini artırır 6,7. Bu hastalarda mekanik ventilasyon süresi de daha uzundur ve medyan mekanik ventilasyon süresi 7 ila 12 gün arasında değişmektedir ${ }^{14}$. $\mathrm{Bu}$ nedenle daha uzun sedasyon süresine ihtiyaç duyulmaktadır. $\mathrm{Bu}$ uzun süreli sedasyon süreleri, ilaç birikimine, toleransa ve taşiflaksiye ve ayrıca ilaçların istenmeyen yan etkilerine yol açabilir, bu hasta grubunda özellikle sorunludur ${ }^{15}$.

\section{Sedatif-Analjezik Ajan Seçimi}

$\mathrm{Bu}$ hastalarda sedasyon için ajan seçerken, multidisipliner bir ekibin (yoğun bakım doktoru, yoğun bakım hemşiresi, eczacı, farmakolog vb) vaka bazında uygun sedatif seçimini gözden geçirmesi ve karar vermesi zorunludur. Protokollü, hemşire kontrollü sedasyonun; sedasyon gereksinimlerini, mekanik ventilasyon süresini ve YBÜ'de kalış süresini azalttığı gösterildiğinden, protokollü bir sedasyon rejimi ile başlamak uygun olabilir ${ }^{16}$. Protokolden sapmalar ve bireyselleştirilmiş bakıma ihtiyaç duyulabilen durumlar net olarak belli olmalıdır. COVID19'lu kritik hastalarda akut böbrek hasarının (AKI) yaygın olduğunu ve insidansının \%25 kadar yüksek olduğunu bildirilmiştir ${ }^{17,18}$. Sedoanaljezi planlamasında ve titrasyonunda bu konuda dikkatli olunması gerekmektedir.

Büyük bir akademik tıp merkezinin birden fazla yoğun bakım ünitesinde (YBÜ) Covid-19 kritik bakım hastalarının sedoanaljezi gereksinimleri araştırılmıștır ${ }^{6}$. Mekanik ventilasyonun ilk 10 günü boyunca COVID-19'lu kritik hastalarda sedasyon uygulamalarının retrospektif, tek merkezli bir kohort çalışması olarak planlanmıștır. Çalışma popülasyonu, COVID- 19'lu, mekanik olarak ventile edilen kritik durumdaki 86 hastadan oluşan ardışık bir kohorttur. Sedoanaljezi ilaçları, dozları, ilaç kombinasyonlarını ve uygulama süresini karakterize eden veriler günlük olarak toplanmıștır. Bu veriler, COVID-19'u olmayan kritik hastaların sedasyonuna yönelik yayınlanmış önerilerle karşılaştırılmıştır. İlaç dozları, uygulanan ilaç sayısı, temel hasta özellikleri ve inflamatuar belirteçler arasındaki ilişkiler araştırılmıştır. Çalışma grubu arasında propofol ve hidromorfon en yaygın başlangıç ilaç kombinasyonuydu ve bu ilaçlar belirli bir günde hastaların sırasıyla $\% 100$ ve $\% 88$ 'inde kullanılıyordu. Hastalar için sedatif ve analjezik infüzyonların dozları ilk 10 gün içinde artmıștır -propofol (hastaların \%48'i), deksmedetomidin (\%29), midazolam $(\% 7,7)$, ketamin $(\% 32)$ ve hidromorfon (\%38)-. Aynı anda uygulanan sedatif ve analjezik ajan sayısı her hasta için zamanla artmış, hastaların \%50'sinden fazlası 2 . günde 3 veya daha fazla ajana ihtiyaç duymuşlardır. Üç veya daha az ajan gerektiren hastalarla karşılaştırıldığında, 3'ten fazla ajan gerektiren grup; ortalama olarak daha genç, vücut kitle indeksi daha yüksek, serum ferritin ve laktat dehidrojenaz konsantrasyonları daha yüksek, daha düşük PaO2:FIO2'ye aranlarına sahip olanlar ve nöromüsküler blokör gerektiren hastalar olarak saptanmıştır. Sonuç olarak; kritik hastalığı olan diğer popülasyonlarda kılavuzlar tarafından önerilen sedasyon uygulamalarına kıyasla, COVID-19'lu kritik hastalığı olan, mekanik olarak ventile edilen hastalarda yüksek sedoanaljezik ihtiyacı olmuştur.

Multidisipliner ekipler, gereksiz kullanımı ve israfı sınırlandırırken terapiyi bireyselleştiren koruma planları uygulamalıdır.

\section{Analjezikler}

Opioidler, kritik hastalarda sedasyon ve analjezi yönetiminin temel taşını oluşturur. Ağrı, yoğun bakım ünitesinde her yerde mevcuttur ve diğer etiyolojilerin yanı sıra uzun süreli hareketsizlik, 
kalıcı cihazlar ve invaziv prosedürlere maruz kalma ile ilişkilendirilir9. Kritik hastalarda ağrının yönetimine, önce ağrının tedavi edilmesini veya ağrı yönetiminin temel dayanağı olarak opioidlerle analgosedasyonun (örn., önce analjezi veya analjezi bazlı) kullanılmasını öneren konsensüs kllavuzları tarafından öncelik verilir ${ }^{11}$. Opioidler, nosisepsiyonda yer alan mü-opioid reseptörü dahil olmak üzere çeşitli farklı reseptörlere etki eder. Opioidler, hastanın yaşayabileceği ağrı düzeyine bağlı olarak bolus veya infüzyon şeklinde uygulanabilir. Aktif metaboliti olmayan ve yüksek lipofilisiteye sahip olan fentanil, yaygın olarak sürekli infüzyon olarak kullanılır. Morfin ve hidromorfon, yoğun bakım hastalarında ağrı tedavisinde kullanılan diğer ilaçlardır.

COVID-19'lu kritik hastalarda akciğer koruyucu ventilasyonu kolaylaştırmak için sıklıkla gerekli olan uzun süreli opioid infüzyonlarının istenmeyen etkileri vardır. Bu tür infüzyonların bağırsak hipomotilitesine neden olduğu, beslenme intoleransına, beslenmede kesintilere ve uzun süreli yoğun bakımda kalış sırasında yetersiz beslenmeye yol açtı̆̆ bilinmektedir. İlaçlar yağ dokusunda birikebilir ve özellikle uzun "context sensitif half-life" nedeniyle uzun süreli kullanımlarda nörolojik derlenmeyi geciktirebilir. Önceden var olan AKI, ilaç birikimine daha fazla katkıda bulunabilir. Bu infüzyonların aniden kesilmesi yoksunluk sendromununa yol açabilir ve mekanik ventilasyondan ayrılmayı zorlaştırabilir ${ }^{19}$. Uzun süreli tedavi süresi ayrıca tolerans gelişimine ve $B$ ve T hücre aracılı immün disfonksiyon, opioid kaynaklı hiperaljezi $(\mathrm{OIH})$ ve fizyolojik ve psikolojik bağımlılık potansiyeli gibi uzun vadeli olumsuz etkilere yol açabilir. Bu nedenle, COVID-19 pozitif hastalarla hemşire temasının sınırlandırılması da dahil olmak üzere sürekli infüzyon kullanmanın riskleri ve faydaları vaka bazında değerlendirilmelidir ${ }^{20}$. Nadir, ancak korkulan bir komplikasyon, hastalarda artmış torasik ve abdominal kas tonusu geliștiren opioid kaynaklı göğüs duvarı rijiditesidir ${ }^{21}$. Göğüs duvarı rijiditesi gelişen entübe hastalarda artmış hava yolu basınçları ve oksijen desatürasyonu gelişebilir ${ }^{22}$. $\mathrm{Bu}$ komplikasyon, ağır ARDS'li bir COVID-19 hastasında ortaya çıkarsa ölümcül olabilir. Fentanil böbrek fonksiyon bozukluğu olan hastalarda tercih edilen ilaçtır ve COVID-19 hastalarında ilk seçenek olarak düşünülmelidir. Sedatif-hipnotiklerin aşırı kullanımıyla ilişsili iyi bilinen deliryum riskini kabul ederek, sürekli fentanil infüzyonuna dayalı bir rejim düşünülmelidir. Bu infüzyonlar günlük olarak değerlendirilmeli ve ventilatör senkronizasyonunu ve hasta konforunu korumak için minimum dozu koruyacak şekilde titre edilmelidir ${ }^{3}$.

\section{COVID-19 Hastalarında Analjezi İçin Alternatif Tedaviler}

Remifentanil, fentanile benzer farmakodinamik özelliklere sahip seçici bir mu-opioid reseptör agonistidir ve acil durum bakımında düşünülmelidir ${ }^{4}$. Fentanilden farklı olarak remifentanil, kan ve doku esterazları tarafindan hızla metabolize edilir; bu nedenle infüzyon süresinden bağımsız olarak çok kısa bir etki süresi vardır ${ }^{23}$. Remifentanil analjezi için fentanile bir alternatif olabilir, ancak remifentanil kullanımı fentanile kıyasla daha yüksek hipotansiyon insidansı ile ilişkilendirilmiştir ${ }^{24}$.Çok merkezli, çift kör, randomize, kontrollü klinik bir çalışmada, sedasyon ve analjezi için remifentanil ile fentanilin etkinliğini ve güvenliği karşılaștırılmıștır. Araștırmaya karıșık YBÜ mekanik ventilasyonlu hastaları dahil edilmiştir. $\mathrm{Bu}$ çalışma, optimal sedasyon seviyesinde geçen süre açısından, (remifentanilde \%88,3'e karşı fentanilde \%89,3) bir fark olmadığı bildirilmiştir. Ek olarak, remifentanil alan hastalar, fentanil ile karşılaştırıldığında optimal sedasyonda hastalar arasında önemli ölçüde daha az 
değişkenlik sergilemiştir $(\mathrm{p}=0.009)$. Bununla birlikte, kısa yarılanma ömrü nedeniyle remifentanil grubundaki hastalar, -analjezinin hızla sonlanımı nedeniyle- ekstübasyon, postekstübasyon ve sonraki tedaviler sırasinda önemli ölçüde daha uzun süre ağrı yaşamıștır (tüm karşılaştırmalar için p $<0.05$ ). Hemodinamik instabilite veya advers olaylarda hiçbir farklılık saptanmamıştır ${ }^{25}$. Remifentanilin kısa yarılanma ömrü nedeniyle, yoksunluk semptomlarını önlemek için infüzyonunun kesilmesinden önce yeterli ağrı yönetiminin sağlanması önemlidir ${ }^{26}$.

Multimodal bir analjezi yaklaşımı, daha iyi ağrı kontrolünü kolaylaştırabilir ve hastaların opioid gereksinimlerini azaltabilir. "YBÜ'deki Erişkin Hastalarda Ağrı, Ajitasyon/Sedasyon, Deliryum, Hareketsizlik ve Uyku Bozukluğunun Önlenmesi ve Yönetimi"ne İlişkin 2018 yılına ait Klinik Uygulama Kllavuzu (PADIS), asetaminofen, ketamin, pregabalin ve gabapentin, karbamazepin gibi nöropatik ağrı kesici ilaçların kullanılmasını önermektedir. Covid-19 enfeksiyonu olan kritik hastalarda, ağrı yoğunluğunu ve opioid kullanımını azaltmak için hastaların organ yetmezlikleri göz önünde bulundurularak adjuvan ilaçların kullanımı düşünülebilinir ${ }^{11}$.

Opioidler etkili analjezik ajanlar olmalarına rağmen, zayıf sedatif özelliklere sahiptirler ve kas gevşetici gerektiren hastalarda yeterli sedasyon sağlamazlar. Bu nedenle, analjeziye ek olarak uygun sedatif ajan kullanımı hasta bakımını kolaylaştırabilir ve genel hasta güvenliğine katkıda bulunabilir. Çeşitli sedasyon yöntemleri mevcuttur ve sedatif ajan seçimi bireyselleştirilmelidir ${ }^{27}$. Sedatif ajanlar seçilirken yüksek trigliserit düzeyleri, uç organ disfonksiyonları ve artan ilaç klirensi dahil olmak üzere COVID-19 hastalarında belirtilen özellikler dikkate alınmalıdır. Hasta faktörlerine ek olarak, istenen ilaçların mevcudiyeti, ulaşılabilirliği de klinik karar verme sürecine dahil edilmelidir.

\section{Sedatifler}

Yoğun bakım ünitesinde en sık kullanılan sedatif ajanlardan biri, kısa etkili, lipofilik bir fenol türevi olan propofoldür. Propofol, $\gamma$ aminobütirik asit (GABA) reseptörünün işlevini modüle eder ve sonuçta hiperpolarizasyona ve nörotransmisyonun inhibisyonuna yol açar. Propofol, birçok durumda, hızlı etki başlangıcı nedeniyle spesifik durumlarda tercih edilen ajandır. Ek olarak, propofol, nispeten kısa bir başlangıç yarı ömrü ve 4 ila 7 saatlik bir terminal yarı ömrü ile bi-fazik kinetik sergiler ${ }^{28}$. $\mathrm{Ne}$ yazık ki, bu terminal yarı ömür, vücut dokularında birikme nedeniyle uzun tedavi sürelerini takiben uzayabilir. Faydalarına rağmen propofol, COVID-19'lu kritik hastalarda sorun yaratabilecek, iyi belgelenmiş, öngörülebilir yan etkilere sahiptir. Propofol, septik şoklu COVID-19 hastalarında önceden var olan hipotansiyonu kötüleştirebilen sistemik vasküler direnç ve miyokardiyal kontraktilitede doza bağlı bir azalmaya neden olur ${ }^{29}$. Bu hipotansiyon, çoklu organ yetmezliğine yol açabilir veya son organ perfüzyonunun azalmasina neden olabilir. COVID-19'lu hastalarının ayrica miyokard hasarı, viral miyokardit ve stres kardiyomiyopatisi geliştirdiği bilinmektedir ${ }^{30}$ ve miyokard kontraktilitesinde propofolün neden olduğu azalma bu hastalarda iyi tolere edilemeyebilir. Propofolün diğer daha az yaygın yan etkileri arasında hipertrigliseridemi ve pankreatit bulunur. Propofol, \%10 yağ emülsiyonu içeren ürünü nedeniyle hipertrigliseridemiye neden olabilir4.

COVID-19 hastaları hipermetabolik durumları nedeniyle diğer kritik hastalardan daha yüksek düzeyde sedasyona ihtiyaç duyma eğiliminde olduklarından, uzun süreli yüksek doz propofol infüzyonları bağımsız olarak yüksek trigliserit seviyelerine yol açabilir, nihayetinde pankreatite yol açabilir. Geleneksel olarak pankreatit gelişimini önlemek için 500 
mg/dL'yi aşan trigliserit yükselmelerinde hastalarda alternatif ajanlar kullanılır.

Bununla birlikte, COVID-19'lu hastalar, hipertrigliseridemi ile birlikte sekonder hemofagositik lenfohistiyositoz (HLH) ile benzer bir tablo ile başvurabilirler. HLH, aktive edilmiş makrofajların ve lenfositlerin downregülasyonunun olmaması nedeniyle ciddi bir sistemik inflamatuar sendromdur ${ }^{31}$. Bu nedenle, propofol alan COVID-19 hastalarında trigliserit konsantrasyonları daha sık (her 2448 saatte bir) izlenmelidir.

Daha yüksek dozlarda propofolden kaynaklanan bir başka endişe de propofol infüzyon sendromudur (PRIS). PRIS, uzun süreli (>48 saat) ve yüksek doz (>4-5 mg kg-1 sa-1) propofol infüzyonları ile ortaya çıkabilen, ölümcül olsa da, nadir görülen bir durumdur ${ }^{32}$. Asistole yol açan dirençli bradikardi, metabolik asidoz, rabdomiyoliz, hiperlipidemi, karaciğer büyümesi, hiperkalemi ve her bileşenin fizyolojik etkileri ile karakterizedir. Bu önlenebilir komplikasyon, infüzyon durdurularak ve ciddi vakalarda hemodinamik destek, hemodiyaliz veya ekstrakorporeal membran oksijenasyonu gibi destekleyici önlemler verilerek hemen tedavi edilmelidir.

Benzodiazepinler sedasyon için alternatif bir seçenektir. Benzodiyazepinler, GABA'nın etkisini kolaylaştırarak, özellikle sedasyon, anksiyoliz, anterograd amnezi, antikonvülzan özellikler ve kas gevşemesi gibi çok sayıda etki uygular. YBÜ sedasyonu için en sık kullanılan iki benzodiazepin midazolam ve lorazepamdır. Midazolam, sınıfındaki en kısa etkili, suda çözünür ilaçlardan biridir. Kısa, "kontext sensitive half-life"özelliği, sürekli infüzyon olarak uygulanmasınına olanak sağlar33. Midazolam, sitokrom P450 sistemi yoluyla hızla hepatik metabolizmaya uğrar ve sonunda böbrekler tarafından atılan aktif metabolit olan 1-hidroksimidazolam'a dönüşür. Bu aktif metabolit, uzun süreli infüzyonlar sırasında ve böbrek fonksiyon bozukluğu olan hastalarda birikebilir ${ }^{34}$. Ana ilacın ve aktif metabolitinin birikimi nedeniyle başlangıç son dönem böbrek hastalığı (SDBY) veya ABH olan hastalarda midazolam uzun süre uygulanırken dikkatli olunmalıdır ${ }^{35}$. Bu sınıftaki tüm ajanların lipofilik olduğunu ve yağ dokusunda birikeceğini bilmek de önemlidir. Uygunsa günlük sedasyon tatillerinin sağlanması ve en düşük etkili dozun kullanılması birikimi sınırlamaya yardımcı olacaktır ${ }^{3}$. Alternatif olarak lorazepam infüzyonları da sedasyon için kullanılabilir. Lorazepam, midazolam ile karşılaştırıldığında daha uzun etki süresine sahiptir. Ayrıca karaciğer yoluyla böbrekler tarafından atılan inaktif metabolitlere metabolize edilir ${ }^{36}$. Aktif metabolit olmaması nedeniyle böbrek fonksiyon bozukluğu olan hastalarda daha az birikim olabilir ve bu nedenle sürekli renal replasman tedavisi (CRRT) veya hemodiyaliz (HD) alan hastalarda bu ajan tercih edilebilir. $\mathrm{Ne}$ yazık ki, lorazepamın daha uzun yarı ömrü, bağımsız olarak ekstübasyonlardaki gecikmelere katkıda bulunabilir ${ }^{37}$.Ülkemizde şu an itibarı ile lorazepamın intravenöz formu bulunmamaktadır.

Özellikle bu hasta popülasyonunda, benzodiazepinleri kullanırken yoğun bakımcıların karşılaştığı bir diğer zorluk, yoksunluk sendromu gelişme riskidir. ARDS'li hastaların daha yüksek dozlarda ilaç alma olasılıkları daha yüksektir. Bu durum, artan yoksunluk sendromu, ve uzamış mekanik ventilasyon riskini beraberinde getirmektedir $^{19}$. Benzer şekilde, COVID-19 ile ilişkili solunum yetmezliği olan hastalar uzun süre mekanik ventilasyona ihtiyaç duyabilir ve yeterli sedasyon seviyelerine ulaşmak için daha yüksek dozlarda sedatif ajanlara ihtiyaç duyabilir6; bu nedenle, uzun süreli tedavinin riskleri ve faydaları rutin olarak değerlendirilmelidir ${ }^{3}$. Benzodiazepinlerin YBÜ sedasyonu için kullanımı, yaşlı hastalarda daha da belirgin olan artan deliryum riski nedeniyle sınırlıdır ${ }^{38}$. Bu nedenle, birikimi sınırlamak için 
mümkün olduğunda aralıklı benzodiazepin dozları kullanılmalı ve multimodal analjezi ve sedasyon modelleri düşünülmelidir.

Deksmedetomidin, yoğun bakım ünitesinde sedasyon için yaygın olarak kullanılan bir $\alpha 2$ adrenerjik agonisttir. Merkezi ve periferik $\alpha 2$ reseptörlerine bağlanarak sempatik çıkışın azalmasına ve norepinefrin salınımının baskılanmasına neden olur. Sedasyon, anksiyoliz ve analjezi sağlayarak, YBÜ sedasyonu, prosedürel sedasyon ve uyanık fiberoptik entübasyonlar için ideal bir ajandir 39,40 . Deksmedetomidinin opioid gereksinimini azaltmada ve deliryum oranlarını düşürmede rolü vardır ${ }^{39,40}$. Diğer sedatiflerin aksine, deksmedetomidin "respiratuvar drive" üzerinde minimal etkiye sahiptir, bu özelliği onu, hastaları mekanik ventilasyondan ayırırken tercih edilen ajan haline getirir. Deksmedetomidinin, bradikardi, hipotansiyon ve kalp bloğunu içeren yan etkileri vardır ${ }^{40}$. Bu etkiler, kardiyak komplikasyonların sıklıkla eşlik ettiği COVID-19 yoğun bakım hastalarında abartılı olabilir.

Deksmedetomidinin monoterapi olarak kullanıldığında daha hafif sedasyon seviyeleri sağladığı bilinmektedir. Yakın tarihli bir randomize kontrollü çalışma, birincil sedatif olarak deksmedetomidin ile sedasyona tabi tutulan mekanik olarak ventile edilen YBÜ hastalarının, istenen sedasyon seviyesine ulaşmak için sıklıkla ek sedatif ajanlara ihtiyaç duyduğuna dair bulgular ortaya çıkardı ${ }^{41}$. Ventilatör uyumsuzluğu belirtileri göstermeye devam eden veya prone pozisyon gerektiren COVID-19 hastalarında, deksmedetomidin tek başına istenen sedasyon seviyelerini elde etmek için yeterli olmayabilir ${ }^{3}$. Ek olarak, uzun süreli infüzyonlar da tolerans gelişimine yol açabilir ${ }^{42}$.

Ketamin, yoğun bakım ünitesinde analjezik ve sedatif-hipnotik ajan olarak kullanılan bir $\mathrm{N}$ metil-D-aspartat (NMDA) reseptör antagonistidir. Ketamin, eksitatör amino asit glutamatın iletimini bloke ederek, NMDA reseptörlerinin rekabetçi olmayan bir inhibitörü olarak görev yapar. Kritik durumdaki travma hastalarında hem postoperatif analjezi hem de akut ağrı yönetimi için giderek daha fazla kullanılmaktadır ve bu hastalarda opioid kullanımını azalttığı gösterilmiștir ${ }^{43}$. Subanestezik dozlarda, ketamin, toplam opioid gereksinimlerini önemli ölçüde azaltırken etkili analjezik özelliklere sahiptir ${ }^{44}$. Güncel bir çalışmada, ek olarak kontinü ketamin infüzyonu uygulamasının, mekanik ventilasyon uygulanan hastalarda, hedef sedasyon aralığında geçen süreyi iyileștirirken, analjezik ve sedatif doz ihtiyacını azaltıcı etkiye sahip olduğunugöstermiştir ${ }^{45}$. Psikotomimetik etkileri ve deliryuma neden olma eğilimi nedeniyle ketamin kullanımı eskiden beri sınırlandırılmıștır. Bununla birlikte, bu psikotomimetik etkiler doza bağımlıdır ve birlikte düşük doz benzodiazepin uygulamasıyla azaltılabilir ${ }^{46}$. Küçük dozlarda ketamin, miyokardiyal depresyon olmaksızın sempatomimetik bir etki gösterir ${ }^{47}$. Ketamin trakeobronşiyal sekresyonları artırabilir, bu da solunum yolu inflamasyonu ve hasarlanmasından kaynaklanan aşırı mukus tıkaçlarının yaygın olduğu COVID-19 hastalarında zararlı olabilir. Ketamin, hem katekolamin salınımının artması hem de vagal yolların inhibisyonu nedeniyle bronkodilatör etkilere sahiptir ve astım öyküsü ile başvuran hastalarda faydalı olabilir ${ }^{48}$. $\mathrm{Bu}$ nedenle, ketamin, dozlarını ve sürelerini sınırlamak için diğer sedatiflere ek olarak kullanılabilir ve astım hastaları dahil olmak üzere belirli COVID19 hastalarında veya diğer sedatiflerin bulunmadığı veya kullanılamadığı durumlarda alternatif bir ajan olarak düşünülebilir³. Yine de, başlamadan önce kapsamlı bir risk-fayda analizi düşünülmelidir ${ }^{49}$.

Sonuç olarak; Covid-19 kritik bakım hastalarında sedasyon uygulamasinın yönetiminde, bireyselleștirilmiş hasta sedasyon ve analjezi yönetimi, çeşitli ajanların yan etki 
profilleri, hastaya ait özellikler ve ilaçların ulaşılabilirliği göz önünde bulundurulmalıdır. Hasta güvenliğinin artırılması ve yoğun bakım sonuçlarının iyileștirilmesi temel amaçtır.

Çıkar Çatışması Beyanı: Yazarlar çıkar çatışması olmadığını bildirmişlerdir.

Finansal Destek: Bu çalışma her hangi bir fon tarafından desteklenmemiştir.

Declaration of ConflictingInterests: The authors declare that they have no conflict of

interest.

Financial Disclosure: No financial support was received.

\section{KAYNAKLAR}

1. Zhu N, Zhang D, Wang W, et al; China Novel Coronavirus Investigating and Research Team. A Novel Coronavirus from Patients with Pneumonia in China, 2019. N Engl J Med. 2020 20; 382: 727-33.

2. Bouadma L, Lescure FX, Lucet JC, Yazdanpanah Y, Timsit JF. Severe SARS-CoV-2 infections: practical considerations and management strategy for intensivists. Intensive Care Med. 2020; 46: 579-82.

3. Karamchandani K, Dalal R, Patel J, Modgil P, Quintili A. Challenges in Sedation Management in Critically Ill Patients with COVID-19: a Brief Review. Curr Anesthesiol Rep. 2021; 26: 1-9.

4. Ammar MA, Sacha GL, Welch SC, et al. Sedation, Analgesia, and Paralysis in COVID-19 Patients in the Setting of Drug Shortages. J Intensive Care Med. 2021; 36: 157-74.

5. Adams CD, Altshuler J, Barlow BL, et al. Analgesia and Sedation Strategies in Mechanically Ventilated Adults with COVID-19. Pharmacotherapy. 2020; 40: 1180-91.

6. Balakrishna A, Walsh EC, Hamidi A, et al. An examination of sedation requirements and practices for mechanically ventilated critically ill patients with COVID-19. Am J Health Syst Pharm. 2021;16: doi: 10.1093/ajhp/zxab202. Epub ahead of print.

7. Kapp CM, Zaeh S, Niedermeyer S, et al. The Use of Analgesia and Sedation in Mechanically Ventilated
Patients With COVID-19 Acute Respiratory Distress Syndrome. Anesth Analg. 2020; 131.

8. Chanques G, Sebbane M, Barbotte E, et al. A prospective study of pain at rest: incidence and characteristics of an unrecognized symptom in surgical and trauma versus medical intensive care unit patients. Anesthesiology. 2007; 107: 858-60.

9. Puntillo KA, Max A, Timsit JF, et al. Determinants of procedural pain intensity in the intensive care unit. The Europain(R) study. Am J Respir Crit Care Med. 2014; 189: 39-47.

10. Rotondi AJ, Chelluri L, Sirio C, et al. Patients' recollections of stressful experiences while receiving prolonged mechanical ventilation in an intensive care unit. Crit Care Med. 2002; 30: 746-52.

11. Devlin JW, Skrobik Y, Gelinas C, et al. Executive summary: clinical practice guidelines for the prevention and management of pain, agitation/sedation, delirium, immobility, and sleep disruption in adult patients in the ICU. Crit Care Med. 2018; 46: 1532-48.

12. Hughes CG, McGrane S, Pandharipande PP. Sedation in the intensive care setting. Clin Pharmacol. 2012; 4: 53-63.

13. Martyn JAJ, Mao J, Bittner EA. Opioid tolerance in critical illness. N Engl J Med. 2019; 380: 365-78.

14. Bhatraju PK, Ghassemieh BJ, Nichols $M$, et al. Covid-19 in critically ill patients in the Seattle Region - case series. N Engl J Med. 2020; 382: 201222.

15. Wang W, Xu Y, Gao R, et al. Detection of SARS$\mathrm{CoV}-2$ in different types of clinical specimens. JAMA. 2020.

16. Sessler CN, Pedram S. Protocolized and targetbased sedation and analgesia in the ICU. Anesthesiol Clin. 2011; 29: 625-650.

17. Yang $\mathrm{X}, \mathrm{Yu} \mathrm{Y}, \mathrm{Xu}$ J, et al. Clinical course and outcomes of critically ill patients with SARS-CoV-2 pneumonia in Wuhan, China: a single-centered, retrospective, observational study. Lancet Respir Med. 2020; 8: 475-81.

18. Zhou F, Yu T, Du R, et al. Clinical course and risk factors for mortality of adult inpatients with COVID- 
19 in Wuhan, China: a retrospective cohort study. Lancet. 2020; 395: 1054-62.

19. Cammarano WB, Pittet JF, Weitz S, Schlobohm RM, Marks JD. Acute withdrawal syndrome related to the administration of analgesic and sedative medications in adult intensive care unit patients. Crit Care Med. 1998; 26: 676-84.

20. Tedders KM, McNorton KN, Edwin SB. Efficacy and safety of analgosedation with fentanyl compared with traditional sedation with propofol. Pharmacotherapy. 2014; 34: 643-7.

21. Roan JP, Bajaj N, Davis FA, Kandinata N. Opioids and chest wall rigidity during mechanical ventilation. Ann Intern Med. 2018; 168: 678.

22. Ham SY, Lee BR, Ha T, Kim J, Na S. Recurrent desaturation events due to opioid-induced chest wall rigidity after low dose fentanyl administration. Korean J Crit Care Med. 2016; 31: 118-22.

23. Egan TD, Lemmens HJ, Fiset $P$, et al. The pharmacokinetics of the new short-acting opioid remifentanil (GI87084B) in healthy adult male volunteers. Anesthesiology. 1993; 79: 881-92.

24. Joshi GP, Warner DS, Twersky RS, Fleisher LA. A comparison of the remifentanil and fentanyl adverse effect profile in a multicenter phase IV study. J Clin Anesth. 2002; 14: 494-9.

25. Muellejans B, López A, Cross $\mathrm{MH}$, et al. Remifentanil versus fentanyl for analgesia based sedation to provide patient comfort in the intensive care unit: a randomized, double-blind controlled trial [ISRCTN43755713]. Crit Care. 2004; 8: R1-R11.

26. Wilhelm W, Kreuer S. The place for short-acting opioids: special emphasis on remifentanil. Crit Care. 2008;12 Suppl 3(Suppl 3): S5.

27. Roberts DJ, Haroon B, Hall RI. Sedation for critically ill or injured adults in the intensive care unit: a shifting paradigm. Drugs. 2012; 72: 1881916.

28. Sahinovic MM, Struys M, Absalom AR. Clinical Pharmacokinetics and Pharmacodynamics of Propofol. Clin Pharmacokinet. 2018; 57: 1539-58.

29. Marik PE. Propofol: therapeutic indications and side-effects. Curr Pharm Des. 2004; 10: 3639-49.
30. Clerkin KJ, Fried JA, Raikhelkar J, et al. Coronavirus disease 2019 (COVID-19) and cardiovascular disease. Circulation. 2020; 141: 1648-55.

31. Mehta P, McAuley DF, Brown M, et al; HLH Across Speciality Collaboration, UK. COVID-19: consider cytokine storm syndromes and immunosuppression. Lancet. 2020; 28; 395(10229): 1033-1034.

32. Mirrakhimov AE, Voore P, Halytskyy O, Khan M, Ali AM. Propofol infusion syndrome in adults: a clinical update. Crit Care Res Pract. 2015; 2015: 260385.

33. Hughes MA, Glass PS, Jacobs JR. Context-sensitive half-time in multicompartment pharmacokinetic models for intravenous anesthetic drugs. Anesthesiology. 1992; 76: 334-41.

34. Gommers D, Bakker J. Medications for analgesia and sedation in the intensive care unit: an overview. Crit Care. 2008; 12(Suppl 3): S4.

35. Arulkumaran N, Montero RM, Singer M. Management of the dialysis patient in general intensive care. Br J Anaesth. 2012; 108: 183-92.

36. Elliott HW. Metabolism of lorazepam. Br J Anaesth. 1976; 48: 1017-23.

37. Arulkumaran N, Montero RM, Singer M. Management of the dialysis patient in general intensive care. Br J Anaesth. 2012; 108: 183-92.

38. Kok L, Slooter AJ, Hillegers MH, van Dijk D, Veldhuijzen DS. Benzodiazepine use and neuropsychiatric outcomes in the ICU: a systematic review. Crit Care Med. 2018; 46: 1673-1680.

39. Martin E, Ramsay G, Mantz J, Sum-Ping ST. The role of the alpha2-adrenoceptor agonist dexmedetomidine in postsurgical sedation in the intensive care unit. J Intensive Care Med. 2003; 18: 29-41.

40. Piao G, Wu J. Systematic assessment of dexmedetomidine as an anesthetic agent: a metaanalysis of randomized controlled trials. Arch Med Sci. 2014; 10: 19-24.

41. Shehabi Y, Howe BD, Bellomo R, et al. Early sedation with dexmedetomidine in critically ill patients. N Engl J Med. 2019; 380: 2506-2517. 
42. Anand VG. Sedation in intensive care unit: is dexmedetomidine the best choice? Int J Crit Illn Inj Sci. 2012; 2: 3-5.

43. Pruskowski KA, Harbourt K, Pajoumand M, Chui SJ, Reynolds HN. Impact of ketamine use on adjunctive analgesic and sedative medications in critically ill trauma patients. Pharmacotherapy. 2017; 37: 1537-1544.

44. Bell RF, Dahl JB, Moore RA, Kalso E. Perioperative ketamine for acute postoperative pain. Cochrane Database Syst Rev. 2006; 1: CD004603.

45. Garber PM, Droege CA, Carter KE, Harger NJ, Mueller EW. Continuous infusion ketamine for adjunctive analgosedation in mechanically ventilated, critically ill patients. Pharmacotherapy. 2019; 39: 288-96.
46. Green SM, Li J. Ketamine in adults: what emergency physicians need to know about patient selection and emergence reactions. Acad Emerg Med. 2000; 7: 278-281.

47. Saegusa K, Furukawa Y, Ogiwara Y, Chiba S. Pharmacologic analysis of ketamine-induced cardiac actions in isolated, blood-perfused canine atria. J Cardiovasc Pharmacol. 1986; 8: 414-419.

48. Craven R. Ketamine. Anaesthesia. 2007; 62 Suppl 1: 48-53.

49. Manasco AT, Stephens RJ, Yaeger LH, Roberts BW, Fuller BM. Ketamine sedation in mechanically ventilated patients: a systematic review and metaanalysis. J Crit Care. 2020; 56: 80-8. 